\title{
Effect of Chitosan and Chlorocholine Chloride on the Minituberization of Cocoyam (Xanthosoma sagittifolium L. Schott)
}

\author{
MEJANE EKANE Carole ${ }^{1,2 *}$, Djeuani Astride Carole ${ }^{1,2}$, FOTSO $^{1}$, Djoucgoue \\ François Pierre ${ }^{2}$ and Omokolo NDOUMOU Denis ${ }^{1}$
}

\author{
${ }^{1}$ Laboratory of plant physiology, Department of Biological Sciences, Higher Teacher Training College (HTTC), University of \\ Yaoundé I, PO Box 47, Yaoundé-Cameroon; \\ ${ }^{2}$ Department of Plant Biology, Faculty of Sciences, University of Yaoundé I, PO Box: 812 Yaoundé-Cameroon; \\ *mejanecarole@yahoo.com / 237674077553
}

\begin{abstract}
This study was carried out in order to evaluate the effect of chitosan (1,2 and $\left.3 \mathrm{gL}^{-1}\right)$ and chlorocholine chloride $\left(5,10\right.$ and $\left.15 \mathrm{mgL}^{-1}\right)$ on the minituberization of cocoyam (Xanthosoma sagittifolium). Results showed that both phytohormones reduced the growth cycle of cocoyam from 6 to 5months with the best results obtained at the concentrations $2 \mathrm{gL}^{-1}$ and $15 \mathrm{mgL}^{-1}$ for chitosan (CTH) and chlorocholine chloride (CCC) respectively. The average number of leaves was greater in CTH at $2 \mathrm{gL}^{-1}(3.80 \pm 1.40)$ and $10 \mathrm{mgL}^{-1}(3.60 \pm 0.70)$ for CCC. The optimal height of the plant for CTH was obtained at $1 \mathrm{gL}^{-1}(17.87 \pm 5.47 \mathrm{~cm})$ and $15 \mathrm{mgL}^{-1}(21.15 \pm 1.99 \mathrm{~cm})$ for CCC. The average leaves surface was greater at $1 \mathrm{gL}^{-1}\left(36.39 \pm 17.02 \mathrm{~cm}^{2}\right)$ for CTH and $15 \mathrm{mgL}^{-1}\left(25.87 \pm 5.62 \mathrm{~cm}^{2}\right)$ for CCC. The number of minitubers harvested as well as the percentage of tuberization was maximum with 29 minitubers at $2 \mathrm{gL}^{-1}$ and 23 for $15 \mathrm{mgL}^{-1}$. The size of the minitubers was best at $3 \mathrm{gL}$ ${ }^{1}(2.60 \pm 0.26 \mathrm{~cm})$ for CTH and $10 \mathrm{mgL}^{-1}(0.56 \pm 0.27 \mathrm{~cm})$ for CCC. The mass of the minitubers increased with best results obtained at $3 \mathrm{gL}^{-1}(2.80 \pm 0.84 \mathrm{~g})$ and at $10 \mathrm{mgL}^{-1}(0.20 \pm 0.36 \mathrm{~g})$ for $\mathrm{CTH}$ and $\mathrm{CCC}$ respectively.
\end{abstract}

Keywords - chitosan, chlorocholine chloride, minitubers, minituberization,Xanthosoma sagittifolium.

\section{INTRODUCTION}

Cocoyam (Xanthosoma sagittifolium) is among the world's six most important root and tuber crops [1].It is pantropical and has been domesticated in most communities in Oceania, Africa, and Asia [2]providing sustenance for over 400 million people $[3,4]$.Africa is the major producer with West and Central Africa, notably, Nigeria, Ghana, and Cameroon contributing to over $60 \%$ of the total African production [5].Thus, the importance of cocoyam to regional food security cannot be overstated. In spite of this growing importance, the production of cocoyam has been stagnant for many years. This is mainly due to (1): the low productivity of planting material [6],(2): the low availability of traditional planting material (corm cuttings) and (3): viral and fungal infections [7].In Cameroon, the main pathogen of cocoyam is Pythium myriotylum, which causes root rot and is responsible for up to $90 \%$ loss in yield in some plantations[8].Meristem culture technique is used to produce plants free of viruses and fungi especially in vegetative propagated plants [9].Plant tissue culture techniques have becomeapowerful tool for propagation of cocoyam to overcomemany problems facingtraditional methods of propagation. Different explants were used to produce disease free planting materials [10].

Many authors have shown that it is possible to produce tubers in in vitro conditions and that the tubers can be considered as seeds through the technique of microtuberization (in vitro) or minituberization (in vivo) [11].It has been showed that the addition of silver nitrate in the medium of microtuberization permits to inhibit the activity of ethylene what favorizes the good unrolling of tuberization in Irish potatoes [12].In agriculture, chitosan is used primarily as a natural seed treatment and plant growth enhancer, and as an ecologically friendly biopesticide substance that boosts the innate ability of plants to defend themselves against fungal infections [13].Agricultural applications of chitosan can reduce environmental stress due to drought and soil deficiencies, strengthen seed vitality, improve stand quality, increase yields, and reduce fruit decay of vegetables [14].Soluble chitosan helps acclimatization in vivo, and increase yield and seed quality of minitubers of treatments of different concentrations with 
best minituber number and yield in controlled conditions also increased as shown in the work done on potato by [15].Chlorocholine chloride (CCC) is a biosynthesized inhibitor widely used in tissue culture media to promote microtuber formation [16].Although CCC stimulates tuber initiation by recalcitrant genotypes, it can inhibit microtuber growth in Solanum tuberosum cultivars that form tubers readily in its absence [17].

This research was aimed at studying the effect of chitos an and chlocholine chloride on the minituberization of cocoyam (Xanthosoma sagittifolium L. Schott). More specifically; to produce vitro plants of white cultivars of Xanthosoma sagittifolium, introduce minituberization in Xanthosoma sagittifolium through the supply of chitosan and chlorocholine chloride.

\section{MATERIAL AND METHOD}

\subsection{Cocoyam plantlets culture}

The plant material constitute of cocoyam vitro plants obtained through in vitro culture of the apex of white cultivar of Xanthosoma sagittifolium harvested from the farm. The explants is sued from plants were disinfected according to the method of [18]modified. After one month of in vitro culture, young cocoyam plants with a root system and well developed leaves, agar was washed away with tap water, and then transferred in plastic pots containing a mixture of black soil, sawdust and sand in the ratio 2:1:1 readably sterilized in an oven (REPLEX mark) at $170^{\circ} \mathrm{C}$ for 48 hours. The union (pots + plantlets) were placed in the culture room. The union was then watered with tap water in the morning before sunrise and in the evening after sunset. The plants were head dressed with a transparent lid to keep a high humidity. After 14 days, the lids were taken off. The union was again left for 14 days before being transferred out of the culture room away from precipitations and sun rays. After others 14 days of acclimatization in ambient temperature, the plantlets were thus ready for the different treatments. The numbers of leaves were counted, height of plants measured with a ruler and the leaf surface was gotten by measuring the length and width and their averages were later calculated.

\subsection{Effect of chitosan and Chlorocholine chloride on the growth of cocoyam}

\subsubsection{Morphological analysis}

2.2.1.1. Treatment of plantlets and induction of minitubers

The induction of minitubers was realized on the action of chitosan $(\mathrm{CH})$ and chlorocholine chloride (CCC) Thus, different treatments were realized. For each treatment, 45 plantlets were used divided in to 3 plots of 15 plantlets each. $10 \mathrm{~mL}$ of the mineral solution (constituted of macro and micro elements presents in the Murashige and Skoog solution) [19]were supplied to the plantlets every 10 days. The treatments of plantlets placed in plots with $5 \mathrm{ml}$ of different concentrations Chitosan ( $1 \mathrm{~g} / \mathrm{L}, 2 \mathrm{~g} / \mathrm{L}$ and $3 \mathrm{~g} / \mathrm{L})$ and chlorocholine chloride $(5 \mathrm{mg} / \mathrm{L}, 10 \mathrm{mg} / \mathrm{L}$ and $15 \mathrm{mg} / \mathrm{L}$ ) was apply after every 20 days. On day 100, the harvest took place due to total yellowing of the leaves of the treated plantlets.

The harvested minitubers were weighed and their height measured according to the different treatments and compared to the control.

\subsubsection{Statistical analysis}

During induction of minituberization, the height of plants was measured until harvest. The minitubers harvested was weight and their number was also determined. The percentage of tuberization was also determined for each treatment. All the statistical analysis were done using excel for the treatment and realization of curves and histograms. Student-Newman Keul's and Duncan's test with the least significant difference of $5 \%$ were used for the comparative analyses of the results with the help of SPSS 16.0.

\section{RESULTS AND DISCUSSIONS}

\subsection{Morphological analysis of cocoyam plantlet during minituberization}

3.1.1. Average number of leaves of plants per treatment with time

The average number of leaves in the presence of $\mathrm{CH}$, increased in all treatments from $\mathrm{D}_{0}$ and then decrease till $\mathrm{D}_{100}$ with the highest obtain with $2 \mathrm{~g}$ on $\mathrm{D}_{40}$ of $3.80 \pm 1.40 \mathrm{~b}$ and the lowest at $3 \mathrm{~g}$ on $\mathrm{D}_{100}$ of $1.90 \pm 0.57 \mathrm{c}$. There exist no significant difference between the control $1 \mathrm{~g}$ but it exists between the control, $2 \mathrm{~g}$ and $3 \mathrm{~g}$. (Table.1). Also with CCC there exist a significant between the control, $5 \mathrm{mg}$ and $15 \mathrm{mg}$ on $\mathrm{D}_{0}, \mathrm{D}_{40}$ and $\mathrm{D}_{80}$ as well as $10 \mathrm{mg}$ from $\mathrm{D}_{20}$ to $\mathrm{D}_{100}$. The highest was obtained with $10 \mathrm{mg}$ on $\mathrm{D}_{20}$ of $3.60 \pm 0.70 \mathrm{~b}$ and the lowest with $5 \mathrm{mg}$ on $\mathrm{D}_{100}$ of $2.10 \pm 1.29 \mathrm{a}$ (Table.1).

\subsubsection{Average height of $X$. sagittifolium plants per treatment with time}

There exist a significant difference between the control, $2 \mathrm{~g}$ $\left(\mathrm{D}_{40}-\mathrm{D}_{100}\right)$ and $3 \mathrm{~g}\left(\mathrm{D}_{80}-\mathrm{D}_{100}\right)$ but no significant difference between the control and $1 \mathrm{~g}$ (Table.1). The maximum average height for plants treated with $\mathrm{CTH}$ was obtained with $1 \mathrm{~g}$ on $\mathrm{D}_{20}$ of $17.87 \pm 5.20 \mathrm{ab} \mathrm{cm}$ and the minimum with the control on $\mathrm{D}_{80}$ of $8.69 \pm 3.76 \mathrm{ab} \mathrm{cm}$. In the presence of 
$\mathrm{CCC}$, the average height of the plants decreased from $\mathrm{D}_{0}$ to $\mathrm{D}_{100}$ in all treatments. There is a significant difference between the control and all treatments on $\mathrm{D}_{0}, \mathrm{D}_{40}$ and $\mathrm{D}_{100}$ with a maximum height obtained with $15 \mathrm{mg}$ on $\mathrm{D}_{20}$ of $21.15 \pm 1.99 \mathrm{a} \mathrm{cm}$ and a minimum with $5 \mathrm{mg}$ on $\mathrm{D}_{60}$ of $8.43 \pm 2.89 \mathrm{a} \quad \mathrm{cm}$ (Table.1).

\subsubsection{Average leaf surface of $X$. sagittifolium plants with time}

The average leaf surface of the plants in the presence $\mathrm{CH}$, decreased from $\mathrm{D}_{0}$ to $\mathrm{D}_{20}$ in all treatments including the control with the lowest value of $12.07 \pm 12.31 \mathrm{a} \mathrm{cm}^{2}$ obtained on $\mathrm{D}_{40}$ and the maximum average leaves surface with $1 \mathrm{~g}$ on $\mathrm{D}_{0}$ and $\mathrm{D}_{0}$ and $\mathrm{D}_{40}$ of $36.39 \pm 17.02 \mathrm{~d} \mathrm{~cm}^{2}$ and $31.26 \pm 16.37 \mathrm{c}$ $\mathrm{cm}^{2}$ respectively (Table.1). Also with $\mathrm{CCC}$, the average number of leaf surface increased from D0 to D40 with a maximum of $25.87 \pm 5.62 \mathrm{~cm}^{2}$ at $15 \mathrm{mg} / \mathrm{L}$ on $\mathrm{D}_{40}$. After $\mathrm{D}_{40}$, the average leaf surface decreased and the lowest value of $10.65 \pm 5.57 \mathrm{a} \mathrm{cm}^{2}$ was obtained at $5 \mathrm{mg} / \mathrm{L}$ on $\mathrm{D}_{80}$. There exist a significant difference between the control and $5 \mathrm{mg}$ from $\mathrm{D}_{60}-\mathrm{D}_{100}$ and with $10 \mathrm{mg}$ and $15 \mathrm{mg}$ from $\mathrm{D}_{0}-\mathrm{D}_{80}$ (Table.1).

Table.1: Effect of chitosan and chlorocholine chloride on the growth of cocoyam plants

\begin{tabular}{|c|c|c|c|c|c|c|c|c|}
\hline \multirow{3}{*}{ Parameters } & \multirow{3}{*}{$\begin{array}{l}\text { Times } \\
\text { (days) }\end{array}$} & \multicolumn{7}{|c|}{ Treatments } \\
\hline & & \multirow[t]{2}{*}{ control } & \multicolumn{3}{|c|}{ CTH (g/L) } & \multicolumn{3}{|c|}{$\mathrm{CCC}(\mathrm{mg} / \mathrm{L})$} \\
\hline & & & $\mathbf{1}$ & 2 & 3 & 5 & 10 & 15 \\
\hline \multirow{6}{*}{$\begin{array}{l}\text { Average } \\
\text { Height of } \\
\text { plants (HP) } \\
(\mathrm{cm})\end{array}$} & D0 & $15.08 \pm 2.96 \mathrm{a}$ & $17.87 \pm 5.47 \mathrm{abc}$ & $15.59 \pm 4.81 \mathrm{a}$ & $16.41 \pm 5.73 \mathrm{a}$ & $15.33 \pm 3.29 \mathrm{ab}$ & $20.44 \pm 4.38 b$ & $21.06 \pm 2.07 \mathrm{~b}$ \\
\hline & D20 & $14.69 \pm 3.21 \mathrm{a}$ & $17.87 \pm 5,20 \mathrm{ab}$ & $15.94 \pm 4.70 \mathrm{a}$ & $16.82 \pm 6.97 \mathrm{a}$ & $15.38 \pm 3.31 \mathrm{a}$ & $20.52 \pm 4.35 \mathrm{a}$ & $21.15 \pm 1.99 \mathrm{a}$ \\
\hline & D40 & $12.70 \pm 3.71 \mathrm{a}$ & $17.83 \pm 5.06 \mathrm{~b}$ & $16.75 \pm 4.65 \mathrm{ab}$ & $16.22 \pm 6.96 a$ & $12.90 \pm 6.00 \mathrm{ab}$ & $20.34 \pm 4.22 \mathrm{a}$ & $20.85 \pm 1.74 \mathrm{ab}$ \\
\hline & D60 & $9.29 \pm 4.69 a$ & $16.45 \pm 4.56 b$ & $15.64 \pm 2.68 b$ & $16.48 \pm 6.47 \mathrm{a}$ & $8.43 \pm 2.89 \mathrm{a}$ & $15.12 \pm 4.88 \mathrm{a}$ & $14.49 \pm 4.44 \mathrm{a}$ \\
\hline & D80 & $8.69 \pm 3.76 \mathrm{ab}$ & $16.89 \pm 5.01 \mathrm{c}$ & $14.65 \pm 3.88 \mathrm{c}$ & $14.98 \pm 7.07 \mathrm{a}$ & $7.71 \pm 3.44 \mathrm{ab}$ & $14.53 \pm 2.82 \mathrm{ab}$ & $12.47 \pm 3.97 \mathrm{ab}$ \\
\hline & D100 & $9.76 \pm 3.21 \mathrm{ab}$ & $14.92 \pm 3.67 \mathrm{c}$ & $15.13 \pm 3.59 c$ & $15.67 \pm 5.54 \mathrm{a}$ & $8.75 \pm 3.22 \mathrm{a}$ & $12.06 \pm 6.15 \mathrm{a}$ & $13.21 \pm 2.67 \mathrm{a}$ \\
\hline \multirow{6}{*}{$\begin{array}{l}\text { Average } \\
\text { Number of } \\
\text { leaves (NL) }\end{array}$} & D0 & $3.20 \pm 1.14 \mathrm{~b}$ & $3.00 \pm 0.82 \mathrm{~b}$ & $2.90 \pm 1.10 \mathrm{ab}$ & $2.20 \pm 0.63 \mathrm{ab}$ & $2.60 \pm 0.52 \mathrm{a}$ & $3.10 \pm 0.57 \mathrm{~b}$ & $3.00 \pm 0.47 \mathrm{c}$ \\
\hline & D20 & $3.10 \pm 0.88 \mathrm{a}$ & $3.20 \pm 1.55 \mathrm{a}$ & $3.60 \pm 1.35 \mathrm{a}$ & $2.70 \pm 1.25 \mathrm{ab}$ & $3.30 \pm 0.48 \mathrm{a}$ & $3.60 \pm 0.70 \mathrm{~b}$ & $3.00 \pm 0.67 b$ \\
\hline & D40 & $2.90 \pm 0.88 \mathrm{ab}$ & $3.00 \pm 1.33 \mathrm{ab}$ & $3.80 \pm 1.40 \mathrm{~b}$ & $2.60 \pm 0.97 \mathrm{ab}$ & $3.00 \pm 0.82 \mathrm{a}$ & $2.50 \pm 1.27 \mathrm{~b}$ & $3.00 \pm 0.94 b$ \\
\hline & D60 & $2.80 \pm 1.14 \mathrm{a}$ & $2.05 \pm 0.85 \mathrm{a}$ & $2.80 \pm 1.32 \mathrm{a}$ & $2.20 \pm 0.92 b$ & $2.40 \pm 0.70 \mathrm{a}$ & $2.40 \pm 1.08 \mathrm{~b}$ & $2.40 \pm 1.06 \mathrm{~b}$ \\
\hline & D80 & $2.80 \pm 0.94 \mathrm{~b}$ & $2.30 \pm 0.68 \mathrm{ab}$ & $2.20 \pm 0.79 \mathrm{ab}$ & $2.00 \pm 0.47 \mathrm{c}$ & $2.50 \pm 1.354 \mathrm{a}$ & $2.40 \pm 1.08 \mathrm{c}$ & $2.80 \pm 1.03 \mathrm{ab}$ \\
\hline & D100 & $2.70 \pm 0.68 \mathrm{a}$ & $2.20 \pm 0.79 \mathrm{a}$ & $2.30 \pm 0.48 \mathrm{a}$ & $1.90 \pm 0.57 \mathrm{c}$ & $2.10 \pm 1.29 \mathrm{a}$ & $2.30 \pm 1.06 \mathrm{abc}$ & $2.60 \pm 1.17 b c$ \\
\hline \multirow{6}{*}{$\begin{array}{l}\text { Average } \\
\text { Leaves } \\
\text { surface (SF) } \\
\left(\mathrm{cm}^{2}\right)\end{array}$} & D0 & $15.87 \pm 6.63 a$ & $36.39 \pm 17.02 \mathrm{~d}$ & $29.79 \pm 7.41 \mathrm{~cd}$ & $26.11 \pm 8.57 b c$ & $16.04 \pm 5.55 \mathrm{a}$ & $20.98 \pm 5.79 \mathrm{ab}$ & $24.31 \pm 5.05 a b c$ \\
\hline & D20 & $15.20 \pm 6.92 \mathrm{a}$ & $29.42 \pm 11.78 b$ & $25.91 \pm 8.29 b$ & $24.56 \pm 11.50 \mathrm{~b}$ & $14.98 \pm 5.30 \mathrm{a}$ & $22.04 \pm 7.12 \mathrm{ab}$ & $23.96 \pm 5.11 b$ \\
\hline & D40 & $12.07 \pm 12.31 \mathrm{a}$ & $31.26 \pm 16.37 \mathrm{c}$ & $28.40 \pm 10.71 b c$ & $26.90 \pm 10.62 b c$ & $12.72 \pm 5.42 \mathrm{a}$ & $20.91 \pm 6.47 \mathrm{ab}$ & $25.87 \pm 5.62 b c$ \\
\hline & D60 & $14.71 \pm 11.89 \mathrm{ab}$ & $26.81 \pm 15.46 \mathrm{c}$ & $24.19 \pm 8.59 b c$ & $26.39 \pm 10.64 \mathrm{c}$ & $11.55 \pm 3.28 \mathrm{a}$ & $21.79 \pm 6.59 b c$ & $18.67 \pm 7.81 \mathrm{abc}$ \\
\hline & D80 & $12.57 \pm 6.37 \mathrm{ab}$ & $26.82 \pm 15.60 \mathrm{c}$ & $21.53 \pm 10.03 b c$ & $22.01 \pm 11.97 b c$ & $10.65 \pm 5.57 \mathrm{a}$ & $22.23 \pm 10.43 b c$ & $17.6 \pm 7.72 \mathrm{abc}$ \\
\hline & D100 & $15.54 \pm 6.19 \mathrm{ab}$ & $20.72 \pm 5.16 c$ & $21.79 \pm 8.69 c$ & $21.92 \pm 8.77 \mathrm{c}$ & $12.37 \pm 5.28 \mathrm{a}$ & $19.17 \pm 9.85 \mathrm{ab}$ & $18.74 \pm 4.41 \mathrm{ab}$ \\
\hline
\end{tabular}

\subsection{Minitubers harvested according to the treatment of chitosan and chlorocholine chloride}

From results, an increase in the number and weight of the minitubers was obtained with best results from CTH treatments compared to CCC treatments. The maximum results of 29 minitubers were obtained at $2 \mathrm{~g} / \mathrm{L}$ with $\mathrm{CTH}$ and 23 minitubers with CCC was obtained at $15 \mathrm{mg} / \mathrm{L}$. The lowest values obtained were 9 minitubers at $3 \mathrm{~g} / \mathrm{L}$ and $4 \mathrm{mg} / \mathrm{L}$ at $5 \mathrm{mg} / \mathrm{L}$ (Fig.1.). 

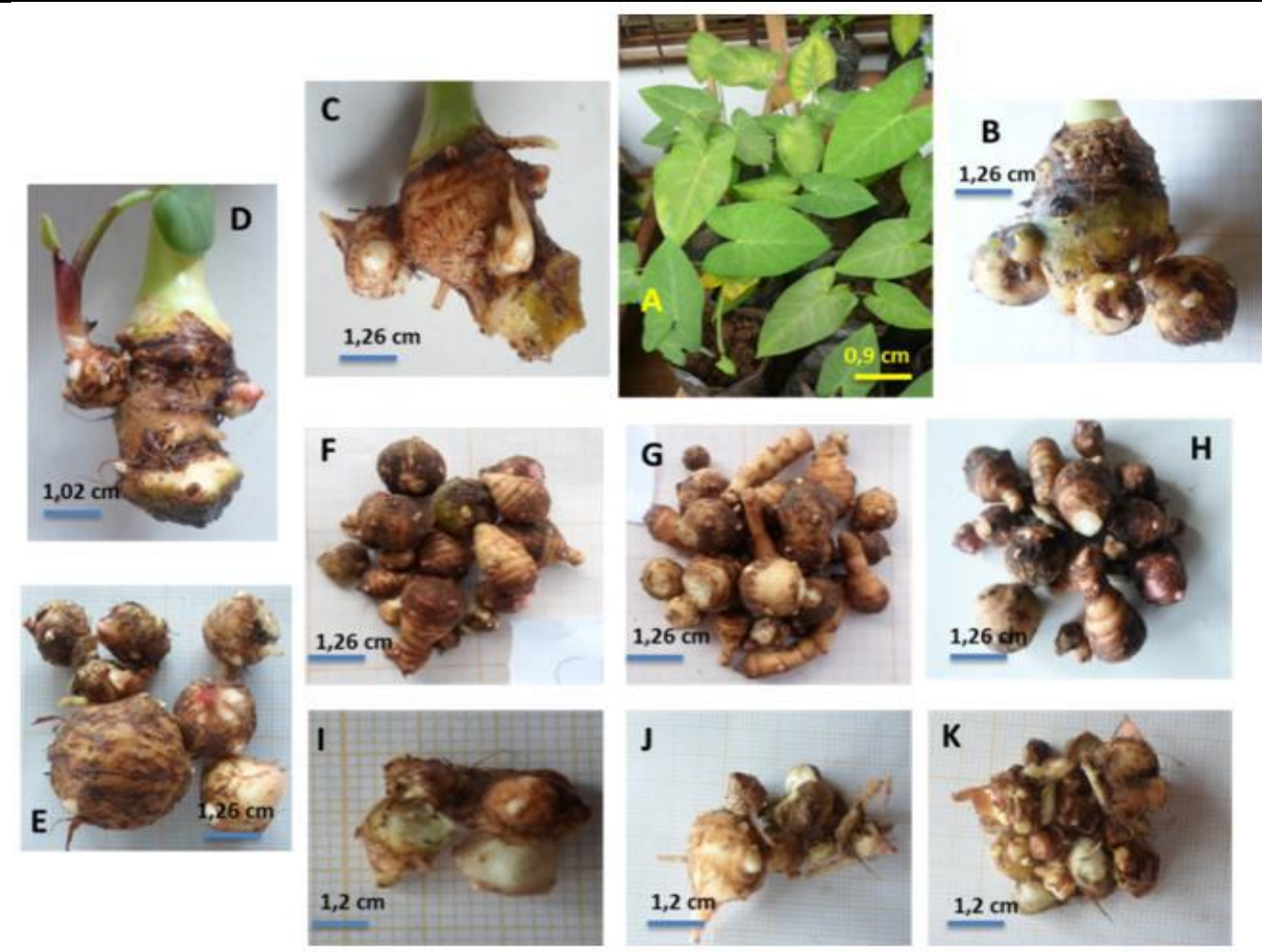

Fig.1: Minitubers harvested: Young plants ready for harvest (A): Plant treated with $C T H(B)$ :Plant treated with $C C C(C)$ : Control(D): Minitubers obtained from the; control(E), $1 \mathrm{~g} C T H(F), 2 g C T H(G), 3 g C T H(H), 5 m g C C C(I), 10 m g C C C(J)$ and $15 g$ $C C C(K)$.
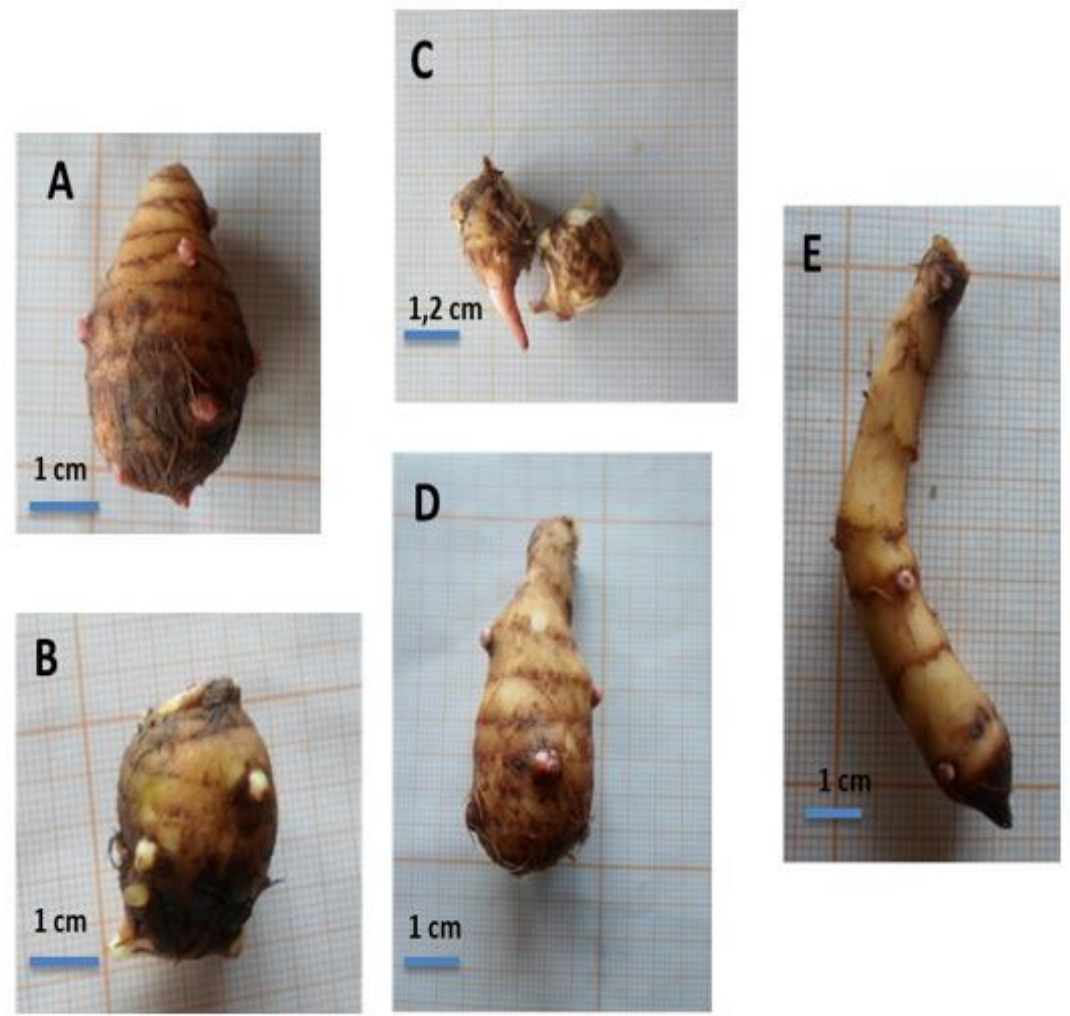

Fig.2: Shape of minitubers harvested: Oval (A), Round (B), Button (C), Pear (D) and crescent (E) 


\subsubsection{Number of minitubers}

The number of minitubers in the presence of $\mathrm{CTH}$, increased with a maximum of 29 minitubers at $2 \mathrm{~g} / \mathrm{L}$ and the lowest number of minitubers of 9 obtained with $3 \mathrm{~g} / \mathrm{L}$ compared to the control of 18 minitubers with a great significance of $5 \%$ existing between all the treatments compared to the control (Fig.3). In the presence of CCC, the number of minitubers obtained increased with the concentration and a maximum of 23 minitubers at $15 \mathrm{mg} / \mathrm{L}$ and the lowest number of minitubers of 4 obtained with 5 $\mathrm{mg} / \mathrm{L}$ with a great significant difference $5 \%$ between all the treatments and the control (Fig.4).

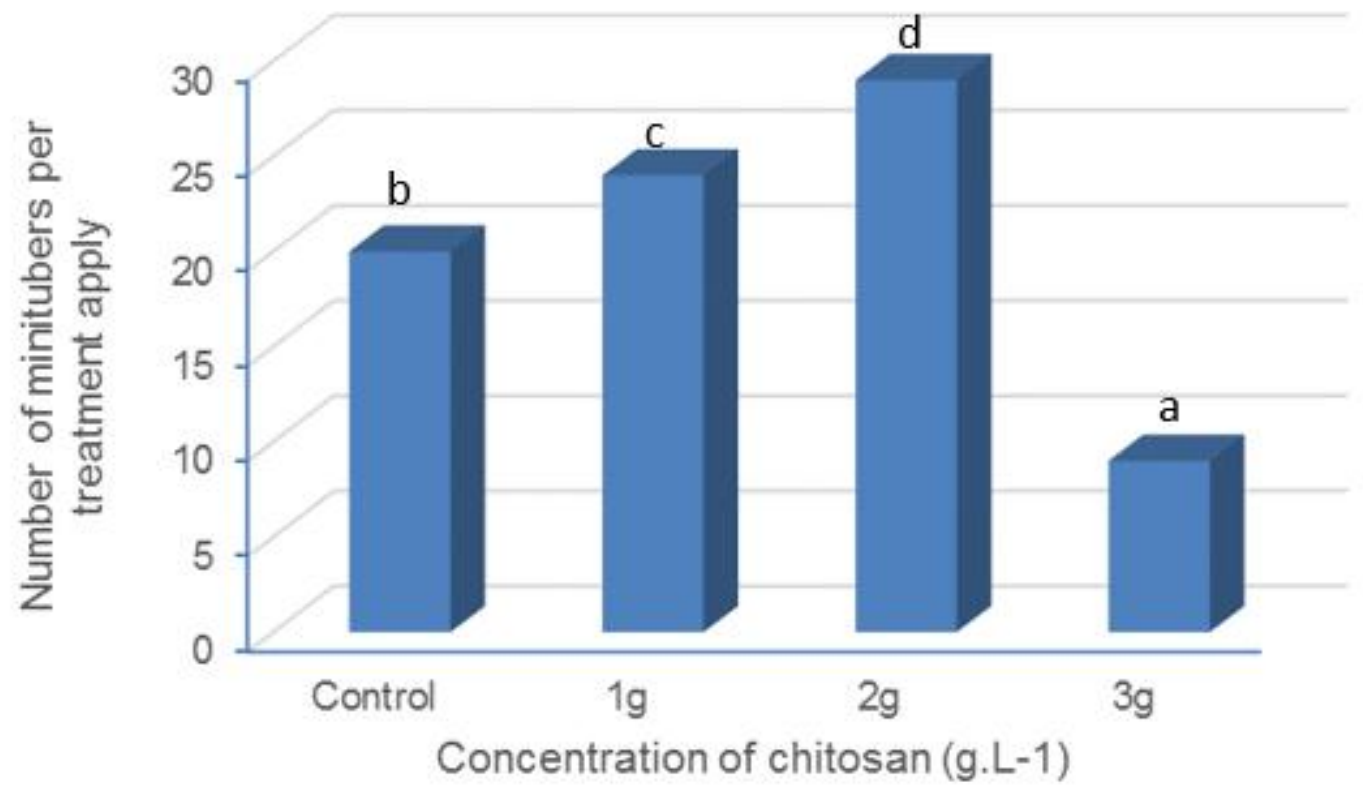

Fig.3: Number of minitubers per treatment of chitosan applied.

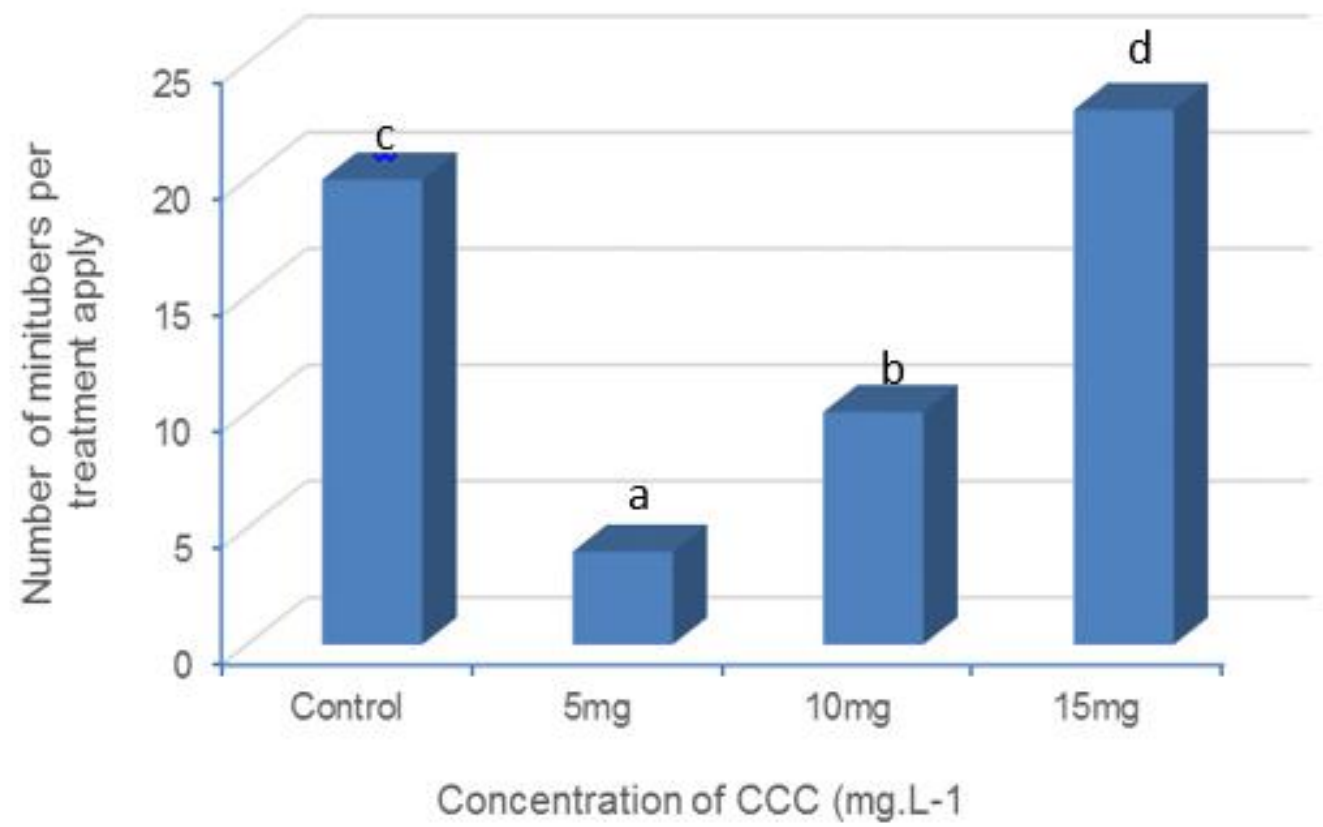

Fig.4: Number of minitubers per treatment of chlorocholine chloride applied. 


\subsubsection{Percentage of tuberization}

The percentage of tuberization in the presence of $\mathrm{CTH}$, increased with a maximum of $92.31 \%$ at $2 \mathrm{~g} / \mathrm{L}$ and the lowest percentage of tuberization of $38.46 \%$ obtained at $3 \mathrm{~g} / \mathrm{L}$ compared to that of the control of $61.54 \%$ and a great significant difference of $5 \%$ between all the treatments and the control (Fig.5). In the presence of CCC, the percentage of tuberization increased with the concentration with a maximum of $61.54 \%$ at $15 \mathrm{mg} / \mathrm{L}$, same obtained with the control hence no significant difference between $15 \mathrm{mg} / \mathrm{L}$ and the control. The lowest percentage of tuberization of 15.39 $\%$ was obtained at $5 \mathrm{mg} / \mathrm{L}$ (Fig.6).

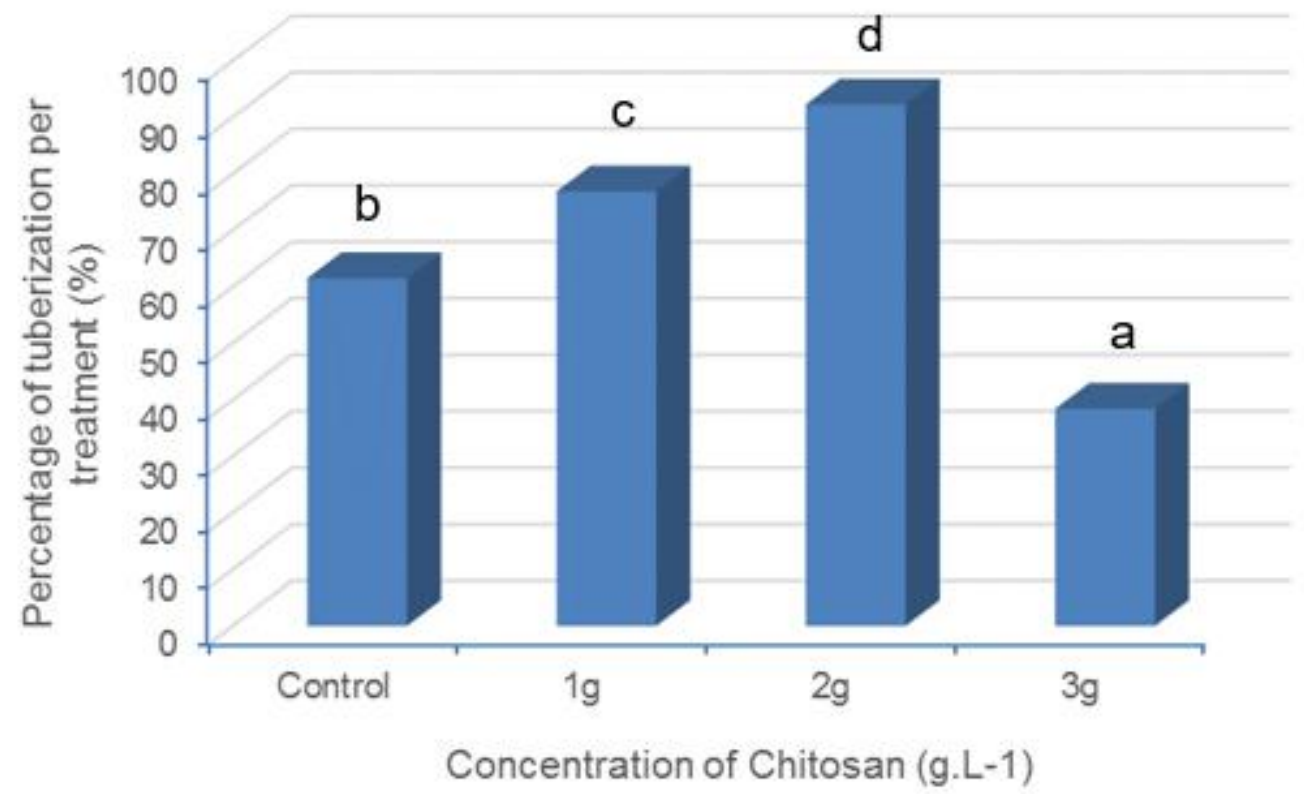

Fig.5: Percentage of tuberization per treatment of chitosan applies

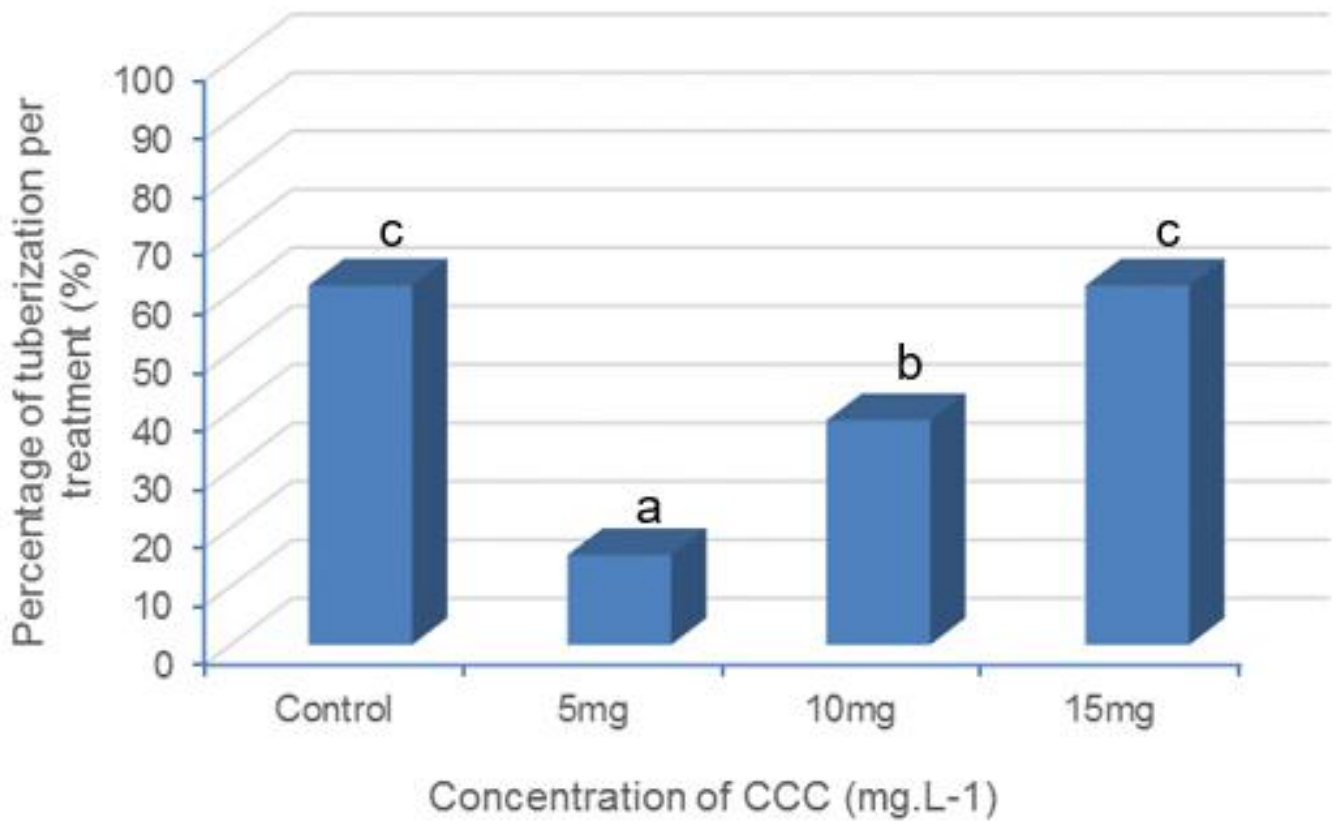

Fig.6: Percentage of tuberization per treatment of chlorocholine chloride apply 
3.2.3. Size of minitubers per treatment

There exist great significant differences between all CTH treatments with a maximum size obtained at $3 \mathrm{~g}$ of $2.6 \pm 0.26 \mathrm{~cm}$ and a minimum of $1.43 \pm 0.82 \mathrm{~cm}$ compared to the control of $0.76 \pm 0.48 \mathrm{~cm}$ (Table.2). There also exist a great significant difference between all treatments of CCC with a maximum size obtained at $10 \mathrm{mg}$ of $0.56 \pm 0.27 \mathrm{~cm}$ and a minimum at $5 \mathrm{mg}$ of $0.24 \pm 0.24 \mathrm{~cm}$ compared to the control (Table.2).
3.2.4. Mass of the minitubers per treatment

For the average mass of minitubers harvested from plants treated with CTH showed a significant difference compared to the control with a maximum mass obtained at $3 \mathrm{~g}$ of $2.8 \pm 0.84 \mathrm{~g}$ and a minimum at $1 \mathrm{~g}$ of $1.47 \pm 0.42 \mathrm{~g}$ (Table.2). There also exist significant differences between all treatments of CCC compared to the control with a maximum value obtained at $10 \mathrm{mg}$ of $0.20 \pm 0.36 \mathrm{~g}$ and a minimum at $5 \mathrm{mg}$ of $0.06 \pm 0.03 \mathrm{~g}$.

Table.2: effect of chitosan and chlorocholine chloride on the size and the mass of minitubers harvested.

\begin{tabular}{cccccccc}
\hline \multirow{2}{*}{ Parameters } & & \multicolumn{5}{c}{ Treatments } \\
\cline { 2 - 7 } & Control & $\mathbf{1}$ & $\mathbf{2}$ & $\mathbf{3}$ & $\mathbf{5}$ & $\mathbf{1 0}$ & $\mathbf{1 5}$ \\
\cline { 2 - 7 } & & $1,43 \pm 0,82^{\mathrm{e}}$ & $1,96 \pm 0,41^{\mathbf{f}}$ & $2,6 \pm 0,26^{\mathrm{g}}$ & $0,24 \pm 0,24^{\mathrm{a}}$ & $0,56 \pm 0,27^{\mathrm{c}}$ & $0,50 \pm 0,22^{\mathbf{b}}$ \\
\hline $\begin{array}{c}\text { Average size of } \\
\text { minituber }(\mathbf{c m})\end{array}$ & $0,76 \pm 0,48^{\mathrm{d}}$ & & & & & & \\
\hline $\begin{array}{c}\text { Average mass of } \\
\text { minituber }(\mathbf{g})\end{array}$ & $0,51 \pm 0,95^{\mathrm{d}}$ & $1,47 \pm 0,42^{\mathrm{e}}$ & $1,80 \pm 0,56^{\mathbf{f}}$ & $2,8 \pm 0,84^{\mathrm{g}}$ & $0,06 \pm 0,03^{\mathrm{a}}$ & $0,20 \pm 0,36^{\mathbf{c}}$ & $0,12 \pm 0,13^{\mathbf{b}}$ \\
& & & & & & & \\
\hline
\end{tabular}

Data sharing the same letter in the same line are significantly different at 5\% level (Duncan's multiple range tests)

\section{DISCUSSION}

The morphological analysis shows that plants treated with chitosan compared to plants treated with CCC permitted to obtain best performances on the quality and quantity of minitubers with relation to those obtained from traditional cuttings. This may be due to the fact that the plantlets are from the origin, exempted from all contaminations which are contrary to traditional cuttings which carry pathogen microorganisms, susceptible of limiting the production of minitubers. This result is in concordance with the work of [20],who showed that the quality of the plant materials influence the production of yam (Discorea alata L.). Their works stipulates that, to obtain minitubers from plantlets, it takes twenty weeks which is in concordance with our work where by the harvest of minitubers took place 171days after planting.

From this work, the average number of leaves, average height of the plants and average leaf surface, increased with the concentration of Chitosan, but decreased with time, this is in agreement with the works of [21],who realized the application of Chitosan solution ranging from 4-250 ppm significantly enhanced the vegetative growth, yield and quality of okra. [22]also remarked that chitosan increased the growth and yield of coffee and had a highly positive correlation with chlorophyll and carotenoid accumulations in the leaves and additionally, may increase mineral uptake and stimulate the coffee growth rate. It was confirmed that chitosan is a second source composed not only of carbon and nitrogen but, some other elements in the chain which are essential minerals for the growth of the plant[23].They also noticed that chitosan may also be attributed to the promoting effects on nutrient uptake and nutritional status: nitrogen, potassium and phosphorus especially result in higher plant growth. Work on soybean in 2010, also noted that even though the mineral composition of the soil that was mixed with chitosan before and after cultivation of soybean, was unchanged [24]. He explained it was because the content of nitrogen, potassium and phosphate significantly increased with the application of chitosan.

Results also shows that the average number of leaves of plants treated with CCC decreased while average height and leaf surface increased with the concentration and time. These results are in agreement with those of [25] on gaur cultivars who reported that exogenous application of CCC significantly increased the leaf surface area per plant contrary to this report, some reports says that exogenous application of CCC, significantly reduced the total leaf area in plants like soybean cultivar [26]and Brassica juncea [27]On the other hand, the beginning of the decrease in number of leaves, height and leaf surface of the plants also marks the beginning of minituberization of cocoyam.

The number of tubers increased with the concentration in the plants treated with chitosan of concentration $1 \mathrm{~g} / \mathrm{L}$ and $2 \mathrm{~g} / \mathrm{L}$. The best tuberization with chitosan was obtained with $2 \mathrm{~g} / \mathrm{L}(92.31 \%)$ and $15 \mathrm{mg} / \mathrm{L}$ $(61.54 \%)$ for CCC. These results are in line with that obtained by [28] on Solanum tuberosum L. which showed 
most effective improved acclimatization of plantlets in the greenhouse as expressed by significance in the number of minitubers and yield of potatoes with $500 \mathrm{mg} / \mathrm{L}$. This can also be explained by the report of chitosan known as a growth promoter in various crops such as soybean sprouts [29].With CCC, the number of minitubers as well as the percentage of tuberization increased with continuous increase of the concentration, this is similar to the results obtained by [30]on potatoes, who realized increasing the rate of $\mathrm{CCC}$ increased the number and average weight of microtubers recorded at $500 \mathrm{mg} / \mathrm{L} \mathrm{CCC}$. The weight and height of the minitubers also increased with the concentration which is in line with the results obtained by [31]on potato, they found that the maximum number of microtubers per plants with $500 \mathrm{mg} / \mathrm{L} \mathrm{CCC}$ and the weight of microtubers, decreased with the rate of $\mathrm{CCC}$ concentration. The highest tuber weight was recorded in the absence of CCC while the minimum at $500 \mathrm{mg} / \mathrm{L}$ (145.7mg) which is in agreement with those of [32]but disagree with those of [33]with relation to the weight. The height of the minitubers treated with CCC are smaller compared to the control and plants treated with chitosan. These results were obtained because according to [29],CCC produces a reduction in the height without malformation by reducing cell elongation and also by lowering cell division.

\section{CONCLUSION}

The general objective of this work was to study the effect of chitosan and chlorocholine chloride on the minituberization of cocoyam (Xanthosoma sagittifolium L. Schott). The results obtained shows that the plantlets which were treated with different concentrations of chitos an $(1 \mathrm{~g} / \mathrm{L}, 2 \mathrm{~g} / \mathrm{L}$ and 3 $\mathrm{g} / \mathrm{L})$ are more productive with best results compared to plants supplied with different concentrations of CCC (5 $\mathrm{mg} / \mathrm{L}, 10 \mathrm{mg} / \mathrm{L}$ and $15 \mathrm{mg} / \mathrm{L}$ ). The morphological studies shows that the best results were obtained from plants treated with chitosan of concentration $2 \mathrm{~g} / \mathrm{L}$. It produced the greatest average number of leaves, height of plants, number of minitubers and weight of minitubers whereas in $\mathrm{CCC}$, the best result was obtained with $15 \mathrm{mg} / \mathrm{L}$.

\section{REFERENCES}

[1] FAO (2012). FAO statisticalyearbook. World food and agriculture. Rome, Italy: Food and Agriculture Organization of the United Nations. Google Scholar

[2] Ramanatha R. V., Matthews P. J., Eyzaguirre P. B., \& Hunter D. (2010). The global diversity of taro: Ethnobotany and conservation. Rome, Italy: Biodiversity International. Google Scholar
[3] Onokpise O.U., J.G. Wutoh, X. Ndzana, J.T. Tambong and M.M. Mebokaet al., 1999. Evaluation of Cocoyam Germplasm in Cameroon. In: Perspective of New Crops and New Uses, Janick, J., (Ed.). ASHS Press, Alexandra, VA., pp: 394-396.

[4] Vaneker K., \&Slaats E. (2013). Mappingediblearoids. Iridescent Icograda, 3, 34-45. Google Scholar

[5] Onyeka J. (2014). Status of Cocoyam (Colocasiaesculenta and Xanthosoma spp.) in West and Central Africa: Production, Household Importance and the ThreatfromLeafBlight. Google $\underline{\text { Scholar }}$

[6] Schafer L.L., 1999. Improvement of cocoyam (Xanthosoma sagittifolium L. Schott) growing system in bamilike land (West-Cameroon). Cahier. Agric., 8: 9-20.

[7] $\mathrm{Xu}$ T., N.D. Omokolo N.G. Tsala and M.E.L. Ngonkeu, 1995. Identification of the causal agent of cocoyam root rot disease in Cameroon. Acta Mycol. Sin., 14: 37-4

[8] Pacumbaba R.P., J.C. Wutoh A.E. Sama J.T. Tambong and L.M. Nyochembeng, 1992. Isolation and pathogenicity of rhyzosphere fungi of cocoyam in relation to cocoyam root rot disease. J. Phytopathol., 135: 265-273.

[9] Abo El-Nil M.M. \&Zettler F.W. (1976). Callus initiation and organdifferentiationfrom shoot tip cultures of Colocasiaesculenta. Plant Sci. Lett. 6:401408.

[10] Behera K.K. \&Sahoo S. (2008). In vitro micropropagation of Colocasiaesculenta (L.)Schott. (cv local-jhankhri) through corm sprouts. Orissa J. Hortic. 36:50-54.

[11] Omokolo N.D., Boudjeko T., Tsafack T., 2003. In vitro tuberization of Xanthosomasagittifolium (L.) Schott: effects of phytohormones, sucrose, nitrogen and photoperiod. Sci. Hort. 98: 337-345.

[12] Zhang Z. J., Li H. Z., Zhou W. J., Tajeuchi X. and Yoneyama K. 2006. Effect of 5-Aminoevulinic acid on the development and salt tolerance of potato (SolanumtuberosumL.) mictrotubersin vitro. Plant Growth Regul.1 (49):27-34

[13] Linden, James C., Stoner, Richard J., Knutson, Kenneth W., Gardner-Hughes, Cecilie A. 2000. "Organic disease control elicitors". Agro Food Industry Hi-Tech11 (5):4-32

[14] Linden J.C. and Stoner R.J., 2007. Pre-harvest application of proprietary elicitor delays fruit senescence. A. Raminaet al. (eds.). Advances in Plant 
Ethylene Research: Proceedings of the 7th International Symposium on the Plant Hormone Ethylene. Symposium Society Experiment .301-302 pp.

[15] Britta Kowalski, Felipe Jimenez Terry, Lidcay Herrera and Daniel Agramonte Peñalver, 2006.Application of Soluble Chitosan in vitro and in the Greenhouse to Increase Yield and Seed Quality of Potato Minitubers.Potato Research. 49: 167-176.

[16] Rosell G., F. G. Bertoldi and R. Tizio. 1987. In vitro mass tuberization as a contribution to potato micropropagation. Potato Res. 30: 111-116.

[17] Vecchio V., S. G. Ferraro, M. T. Pagano and L. Andrenelli. 1994. Effect of saccharose and CCC on in vitro production of microtubers of potato cultivars. Sementi-Elette (Italy). 40(5): 63-68.

[18] Omokolo N.D., Tsala M.G., Kanmegne G. and Balange A.P., 1995.In vitro induction of multiple shoots, plant regeneration and tuberization from shoot tips of cocoyam. C.R. Acad.Sci.318: 773-778.

[19] Murashige T. and Skoog F., 1962.A revised medium for rapid growth and bioassays with tobacco tissue culture.Plant Physiology. 15: 473-497.

[20] Rosell G., F. G. Bertoldi and R. Tizio. 1987. In vitro mass tuberization as a contribution to potato micropropagation. Potato Res. 30: 111-116.

[21] Vecchio V., S. G. Ferraro, M. T. Pagano and L. Andrenelli. 1994. Effect of saccharose and CCC on in vitro production of microtubers of potato cultivars. Sementi-Elette (Italy). 40(5): 63-68.

[22] Yan et al., 2011.Effet de la source de carbone sur la tubérisation. Presses Universitaires de France. 58-66 pp.

[23] Mondal M. M. A., Malek M. A., Puteh A. B., Ishmail M. R., Ashrafuzzaman and Naher L., 2012. Effect of foliar application of chitosan on growth and yield in okra.AJCS.6: 918-921.

[24] Dzung NA, Phuong Khanh VT Dzung TT., 2011.Research on impact of chitosan oligomers on biophysical characteristics, growth, development and drought resistance of coffee. Carbohydrate Polymer 84: 751-755.

[25] Farouk S. and Amany A.R., 2012.Improving growth and yield of cowpea by foliar application of chitosan under water stress. Egypt J. Biol.14: 14-26.

[26] Dzung N. A., 2010. Enhancing crop production with chitosan and its derivatives, In Se-Kwon Kim (Editors), chitin, chitosan, oligosaccharides and their derivatives; biological activities and applications.CRC Pres imprint of Taylor \& Francis Group.623-624 pp.

[27] Afria B.S., Nathawat N.S. and Yadav M.L. 1998.Effect of cycocel and saline irrigation on physiological attributes, yield and its components in different varieties of gaur (Cymposistetragonoloba $\mathrm{L}$. Taub). Indian Journal of plant Physiology. 3(1): 4648.

[28] Abo-El-Kheir M.S.A., Kandil S.A. and Mekki B.B.1994. Physiological response of two soybean cultivars grown under water stress conditions as affected by CCC treatment. Egyptian Journal of physiological Science. 18(1): 179-200.

[29] Lone N.A., 2001.Studies on effect of cycocel and ethrel in association with nitrogen on growth and metabolism of mustard under non-irrigated conditions.Ph.D. Thesis, Aligarh Muslim University, Aligarh, India.31(6): 343-348.

[30] Asghari-Zakaria R., Maleki-Zanjani B. and Sedghi E., 2009. Effect of in vitro chitosan application on growth and minitubers yield of Solanum tuberosum L. Plant Soil Environ.55: 252-256.

[31] Lee Y.U., Kim Y.H. and Kim S.B., 2005. Changes in the respiration, growth and vitamin $\mathrm{C}$ content of soybean sprouts in response to chitosan of different molecular weights. Hort. Science. 40: 1333-1335.

[32] Zakaria M., Hossain M.M., KhalequeMian A., Hossain T. and Uddin Z., 2008.In vitro tuberization of potato influenced by benzyl adenine and chlorocholine chloride.Bangladesh J. Agril. Res. 33 (3): 419-425.

[33] Hossain M.J. and Sultana N.,1998.Effect of benzyl amino purine (BAP) and chloro choline chloride (CCC) on in vitro tuberization of potato.Bangladesh Journal of Agricultural Research. 23 (4): 685-690. 